Physics

AEC Research and Development Report

\title{
NEUTRON AGE IN MIXTURES OF \\ LIGHT AND HEAVY WATER
}

by

J. W. Wade

Experimental Physics Division

June 1956

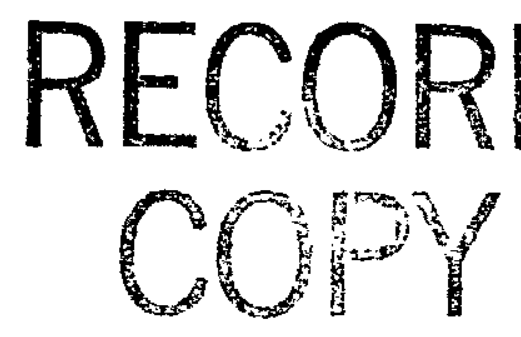

DO NOT RELEASE

FROM FILE

E. I. du Pont de Nomours \& Co.

Explosives Department - Atomic Energy Division Tochnical Division - Savannah River Laboratory 
Th1s report was prepared as an account of Government sponsored work. Ne1ther the United States, nor the Commission, nor any person acting on behalf of the Commission:

A. Makes any warranty or representation, express or Implied, with respect to the accuracy, completeness, or usefulness of the information contained in this report, or that the use of any information, apparatus, method, or process disclosed in this report may not infringe privately owned rights; or

B. Assumes any liabilities with respect to the use of, or for damages resulting from the use of any information, apparatus, method, or process disclosed in this report.

As used in the above, "person acting on behalf of the Commission" includes any employee or contractor of the Commission to the extent that such employee or contractor prepares, handles or distributes, or orovides access to, any information pursuant to his employment or contract with the Commission.

Printed in USA. Price $\$ 0.30$

Avallable from the office of Technical Services

U. S. Department of Commerce Washington 25, D. C. 


\author{
NEUTRON AGE IN MIXTURES OF \\ LIGHT AND HEAVY WATER \\ by \\ James W. Wade \\ Experimental Physics Division
}

June 1956

E. I. du Pont de Nemours \& Co.

Explosives Department - Atomic Energy Division

Technical Division - Savannah River Laboratory

Printed for

The United States Atomic Energy Commission Contract $\operatorname{AT}(07-2)-1$ 


\section{ABSTRACT}

The age for fission neutrons was determined for six mixtures of $\mathrm{D}_{2} \mathrm{O}$ and $\mathrm{H}_{2} \mathrm{O}$ by measuring the neutron slowing-down distributions at $1.4 \mathrm{ev}$. Similar measurements were made in a lattice of aluminum rods in $\mathrm{D}_{2} \mathrm{O}$. In this case, the slowing down distributions in the directions parallel and perpendicular to the rods were different, so that the age-was anisotropic.

External Distribution according to TID-4500 (11th Ed.) 
No. of Coples
(5) AEC, SROO
Aiken, S. C.
(1) R. M. Evans -
B. H. Mackey
J. E. Cole -
M. H. Smith -
W1lmington AED
J. B. Tinker
(1) H. Worthington
1) D. F. Babcock
(1) $\begin{aligned} & \text { R. L. Menegus } \\ & \text { "W" File }\end{aligned}$
(1) S. I. Winde
Engineering Department
$\left\{\begin{array}{l}1 \\ 1 \\ 1 \\ 1 \\ 1 \\ 1 \\ 1 \\ 1\end{array}\right\} \begin{aligned} & \text { J. A. Monier } \\ & \text { W. P. Overbeck } \\ & \text { A. A. Johnson } \\ & \text { P. S. Shane } \\ & \text { F. E. Kruesi } \\ & \text { O. A. Towler } \\ & \text { PRD File }\end{aligned}$
Savannah River Plant
(I) M. H. WahI -
C. W. J. Wende -
W. M. Heston
(I) J.W. Croach
I G. Dessauer
(1) J. L. Crandall
(1) R. R. Haefner -

$n$
$n$
$n$
$n$<smiles>Ic1ccccc1I</smiles>
D. S. Sta John
(1) E. J. Hennelly
(1) G. F. O Neill
(1) J.W. Wade
(15) TIS File
(1) TIS File Record Copy

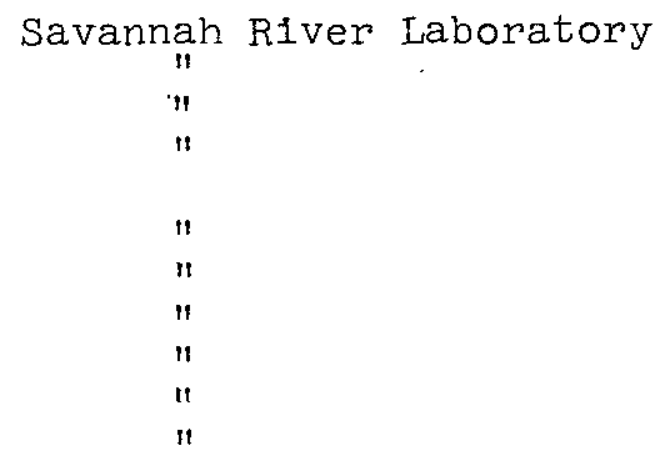




\section{TABLE OF CONTENTS}

\section{LIST OF TABLES AND FIGURES}

INTRODUCTION

SUMMARY

DISCUSSION

Theory 6

Description of Experiments 7

Experimental Facility

Slowing-Down Media

Fission Source and Detectors

Positioning of Source and Detectors

Experimental Procedure

Evaluation of the Data

Results 10

\section{APPENDIX}

Correction of Foil Activities for Finite Size of Source and Detectors

Corrections for Activity Induced in the Foils by High Energy Neutrons 


\section{LIST OF TABLES AND FIGURES}

Table

I Measurements in $\mathrm{Al}_{-}-\mathrm{D}_{2} \mathrm{O}$ Lattice

Page

II Measurements in 99.8 Per Cent $\mathrm{D}_{2} \mathrm{O}$

15

II Measurements in 99.0 Per Cent $D_{2} \mathrm{O}$

16

17

IV Measurements in 98.4 Per Cent $\mathrm{D}_{2} \mathrm{O}$

$\mathrm{V}$ Measurements in 95.3 Per Cent $\mathrm{D}_{2} \mathrm{O}$

19

VI Measurements in 94.0 Per Cent $\mathrm{D}_{2} \mathrm{O}$

20

VII

Measurements in 91.8 Per Cent $\mathrm{D}_{2} \mathrm{O}$

21

VIII

Summary of Age Measurements

22

Figure

Simplified Elevation of the Exponential and Standard Pile

$\underline{\text { Page }}$

2 Diagram of $\mathrm{Al}-\mathrm{D}_{2} \mathrm{O}$ Lattice

23

24

3 Indium Fo1.1, Cadmium Box, Aluminum Foil

Holden, and Fission Source

25

4 Experimental Assembly for Measurements in the $\mathrm{H}_{2} \mathrm{O}-\mathrm{D}_{2} \mathrm{O}$ Mixtures

26

5 Experimental Assembly for Radial and Vertical Traverses in the $\mathrm{A}_{2}-\mathrm{D}_{2} \mathrm{O}$ Lattice

6 In $\mathrm{Ar}^{2}$ vs. $\mathrm{r}$ for 94.0 Per Cent $\mathrm{D}_{2} \mathrm{O}$

7 Ar ${ }^{2}$ vs. $r$ for 94.0 Per Cent $\mathrm{D}_{2} \mathrm{O}$

$8 \mathrm{Ar}^{4}$ vs. $r$ for 94.0 Per Cent, $\mathrm{D}_{2} \mathrm{O}$

9 In $\mathrm{Ar}^{2}$ vs. $\mathrm{r}-\mathrm{H}_{2} \mathrm{O}-\mathrm{D}_{2} \mathrm{O}$ Mixtures

In $\mathrm{Ar}^{2}$ vs. $\mathrm{r}-\mathrm{Aluminum}-\mathrm{D}_{2} \mathrm{O}$ Lattice

11 Age to Indium Resonance vs. Moderator Purity

I2 Geometric Correction Factor vs. Distance

13 Correction of Foil Activity for High Energy Neutrons vs. r 
NEUTRON AGE IN MIXTURES OF

LIGHT AND HEAVY WATER

\section{INTRODUCT..ON}

Measurements of the neutron age $(1)$ in mixtures of light and heavy water were undertaken as part of a program to study the effects of contamination by light water in reactors moderated with heavy water. The only previous work in this field is a single measurement of the neutron slowing-down distribution in 99.8 per cent $\mathrm{D}_{2} \mathrm{O}^{(2)}$. No measurements were available for mixtures of light and heavy water, although some theoretical estimates have been made(3).

It has been predicted that streaming of fast neutrons along aluminum rods will result in an anisotropy of the slowing-down distances $(4)$. The testing of this prediction required that measurements be made in a nonmultiplying lattice of aluminum rods in $\mathrm{D}_{2} \mathrm{O}$.

\section{SUMMARY}

The neutron age from fission energies to $1.4 \mathrm{ev}$ was determined experimentaliy for six mixtures of light and heavy water ranging from 99.8 to 91.8 per cent $\mathrm{D}_{2} \mathrm{O} .^{*}$. The age was evaluated from the distribution of the slowing-down density of neutrons in the moderating media. The slowing-down density was determined by activating cadmium-covered indium foils with neutrons from a "point" fission source.

Over the range of water mixtures studied, the age decreased as a linear function of the $\mathrm{H}_{2} \mathrm{O}$ concentration, within experimental error. The values of the age ranged from $109 \pm 3 \mathrm{~cm}^{2}$ in 99.8 per cent $\mathrm{D}_{2} \mathrm{O}$ to $78 \pm 3 \mathrm{~cm}^{2}$ in 91.8 per cent $\mathrm{D}_{2} \mathrm{O}$.

A large anisotropy in age was found in a lattice of aluminum rods in 99.3 per cent $D_{2} O$. The age, as calculated from the neutron slowing-down density in the direction paraliel to the rods, was 140 $\mathrm{cm}^{2}$, while 1 t was $108 \mathrm{~cm}^{2}$ in the direction perpendicular to the rods. The latter value is equal, within experimental error, to the age for pure moderator.

* Concentrations of $\mathrm{D}_{2} \mathrm{O}$, listed in this report, are in terms of mol per cent $\mathrm{D}_{2} \mathrm{O}$. 


\section{DISCUSSION}

THEORY

The neutron age between two energies is defined as one-sixtr of the mean square distance traveled by the neutrons as they are slowed down from the higher energy to the lower energy. It can be evaluated from the following relation:

$$
\tau\left(E_{O}, E\right)=\frac{\overline{r^{2}}\left(E_{O}, E\right)}{6}=\frac{\int_{V} r^{2} q(r, E) d v}{6 \int_{V} q(r, E) d v}
$$

where

$$
\begin{aligned}
\mathrm{q}= & \text { slowing-down density of neutrons at energy } E, \\
& \text { neutrons }-\mathrm{cm}^{-3}-\mathrm{sec}^{-1} \\
E_{O}= & \text { initial energy of the neutrons } \\
E= & \text { lower energy of the neutrons } \\
r= & \text { distance from the source, } \mathrm{cm} \\
V= & \text { volume, } \mathrm{cm}^{3}
\end{aligned}
$$

The neutron age between the energy of fission neutrons and $1.4 \mathrm{ev}$ can be determined by activating a large number of cadmiumcovered indium folls placed at various distances from a fission source. The foil activities are proportional to the slowing-down densities at $1.4 \mathrm{ev}$, as shown below.

The activity of a foil exposed at the distance $r$ from the source of fission neutrons, $A\left(r^{2}\right)$, can be written as

$$
\Lambda(r) \sim \int_{E_{C d}}^{E_{\text {fission }}} \Sigma_{I n}(E) \Phi(E, r) d E
$$

where

$$
\Sigma_{\text {In }}(E) \text { is the macroscopic absorption cross section of indium, }
$$

and

$\Phi(E)$ is the isotropic(5) component of the neutron flux at the energy $E$ and at the distance $r$.

The integration is performed from the energy of the cadmium cutoff to the energy of fission neutrons. The activity of the foil is obtained by averaging the activities of both sides, since this average 
is proportional to the isotropic neutron flux (5).

For nonabsorbing or weakly absorbing media, such as those investigated in this report, Equation 2 can be written (1)

$$
A(r) \sim \int_{E_{C d}}^{E_{\text {fission }}} q \frac{\Sigma_{I n}}{\xi \Sigma_{S}} \frac{d E}{E}
$$

where

\section{$q$ is the slowing-down density}

and

$\xi \Sigma_{\mathrm{S}}$ is the slowing-down power of the moderator.

Since the cross section of indium is nearly zero except at $1.4 \mathrm{ev}$, the foil activity is proportional to the slowing-down density at $1.4 \mathrm{ev}$.

spherical coordinates

In terms of the foil activities, Equation $I$ becomes now, in

$$
\tau(\text { fission to } 1.4 \mathrm{ev})=\frac{\overline{r^{2}}}{6}=\frac{4 \pi \int_{0}^{\infty} r^{4} A(r) d r}{24 \pi \int_{0}^{\infty} r^{2} A(r) d r}
$$

DESCRIPTION OF EXPERIMENTS

Experimental Facility

The experiments were performed in the aluminum tank of an exponential facility $(6)$. The tank is five feet in diameter and seven feet high. As shown in figure 1 , it is situated directly over the "Standard Pile" or SP(7), a small pile of enriched uranium and graphite that serves as a source of neutrons for the exponential experiment and that is similar to the Thermal Test Reactor $\left.{ }^{8}\right)$.

Slowing-Down Media

Six different mixtures of light and heavy water were used in these experiments. The concentrations of heavy water in each mixture are given in Table VIII. Each value is an average from eight samples that were analyzed by a mass spectrograph.

To study a possible anisotropy of the age, a lattice of aluminum rods was placed in the moderator containing 99.3 per cent $\mathrm{D}_{2} \mathrm{O}$. The experimental lattice consisted of $2 \mathrm{~S}$ aluminum rods one inch in diameter and five feet long that were hung, in clusters of four, from grid beams at the top of the exponential tank. The hexagonal 
lattice of the clusters within the tank is shown in Figure 2. Quatrefoil housing tubes made of $63 \mathrm{~S}$ aluminum were used to accommodate the four rods of each cluster. The cross-sectional areas of a quatrefoil and of a set of four rods were $0.732 \mathrm{in}^{2}$ and $3.14 \mathrm{in}^{2}$ respectively. The total area of each lattice cell was $42.4 \mathrm{in}^{2}$. Thus, the volume ratio of aluminum to water was one to ten.

Fission Source and Detectors

The fission source for the experiments was a stack of ten foils of highly enriched uranium that was irradiated by the thermal neutrons from the SP to produce fission neutrons. The foils were one inch in diameter and 0.005 inch thick. A thin coating of lacquer was applied to each foil to prevent corrosion. The source 1 s shown in Figure 3. Also shown in Figure 3 are the indium foils and cadmium covers that were used to measure the slowing-down distribution. The indium folls were $3 / 4$ inch in diameter, 0.0055 inch thick, and weighed $100 \mathrm{mg} / \mathrm{cm}^{2}$. They were selected from a calibrated set such that, for a given exposure, the activation was the same within $\pm 1 / 2$ per cent. The cadmium covers were 0.030 inch thick.

Positioning of Source and Detectors

Figure 4 shows the aluminum framework and the foil holders that were used in the mixtures of $\mathrm{D}_{2} \mathrm{O}$ and $\mathrm{H}_{2} \mathrm{O}$. The apparatus consisted of an aluminum frame five feet by five feet, and two thinwalled aluminum tubes that formed a crossbar. These tubes had a wall thickness of 0.018 inch and an outside diameter of $1 / 2$ inch. Holes were drilled in the tubes to allow entry of the moderator. The fission source and the foils were attached to the crossbar by means of small aluminum clamps as shown in Figure 4. The frame was placed in the tank so that the fission source was $35 \mathrm{~cm}$ above the bottom of the tank.

Figure 5 shows the apparatus that was used to position the fission source and the foils for the measurements in the $\mathrm{Al}_{1}-\mathrm{D}_{2} \mathrm{O}$ lattice. The fission source was placed inside a one-inch aluminum tube with the plane of the source horizontal. The aluminum tube was placed in one of the channels of the central quatrefoil so that the fission source was approximately $25 \mathrm{~cm}$ from the bottom of the tank.

To make a vertical traverse in the $A 1-D_{2} O$ lattice, most of the cadmium-covered indium folis were placed inside the aluminum tube at various distances from the source and were separated from one another by aluminum spacers. One such aluminum spacer is shown in Figure 3. Six foils were positioned outside the aluminum tube in the moderator, approxinately an inch away from the tube.

Radial traverses in the $A I-D_{2} \mathrm{O}$ lattice were taken along the diameter of the tank in the horizontal plane of the source. Figure 2 shows the path of the radial traverses through the lattice. The indium foils were placed on the aluminum arm, shown in Figure 5, with the plane of the foils perpendicular to the line joining the source and the foils. 


\section{Experimental Procedure}

The slowing-down density of the neutrons at $1.4 \mathrm{ev}$ was proportional to the activity of the cadmium-covered indium foils measured with the U-235 fission source in place, minus the activity observed in a similar run with the fission source removed. The traverse without the fission source measured the activity induced by neutrons from the Standard Pile, while the traverse with the fission source measured the activity induced by neutrons originating in the source as well as in the SP. Therefore, the net activity was induced by neutrons born in the fission source that had been slowed down to $1.4 \mathrm{ev}$.

The activity of the indium foils was determined with two intercalibrated GM tubes. The tubes were Tracerlab TCG-1 counters with a mica end-window. A total of at least 20,000 counts were obtained for each foil. The activity of a foil was taken to be the average of the activities of both sides.

The cadmium-covered foils were spaced at least $8 \mathrm{~cm}$ apart to avoid shadowing of one foil by another. They were placed at a minimum distance of $25 \mathrm{~cm}$ above the graphite pedestal at the bottom of the tank to eliminate the effect of neutrons moderated in the graphite.

Since the folls that were placed along the radius of the tank were closer to the SP than the folls that were placed vertically, the background activity caused by neutrons from the SP, relative to the total activity, was higher for the radial traverses than for the vertical traverses.

To avoid poor counting statistics, the folls were placed in the $\mathrm{Al}-\mathrm{D}_{2} \mathrm{O}$ mixture at distances less than $45 \mathrm{~cm}$ from the source in the radial direction, and less than $70 \mathrm{~cm}$ in the vertical direction. For the same reason, in the $\mathrm{D}_{2} \mathrm{O}-\mathrm{H}_{2} \mathrm{O}$ mixtures, the folls were placed at distances less than $50 \mathrm{~cm}$ from the source.

\section{Evaluation of the Data}

The integrals in Equation 3 were evaluated from the slowingdown density. The age $\tau$, as defined in Equation 3 , is the age measured by means of point detectors and a point fission source. In fitting the experimental results to these formulae, geometric corrections were made to the foil activities to account for the finite size of source and detectors. The formulae for the geometric corrections have been calculated previously(s) and are listed in the Appendix. The geometric corrections to the foil activities never exceeded 0.5 per cent and were less than 0.3 per cent for distances greater than $20 \mathrm{~cm}$ from the source.

Corrections were also made for the activation of the indium by neutrons of energies greater than $1.4 \mathrm{ev}$. The correction for the high energy activation was determined by a technique also described in the Appendix. The corrections for high energy activation were always less than 15 per cent, and were less than 0.5 per cent for distances greater than $25 \mathrm{~cm}$ from the source. 
To evaluate $\tau$ from the corrected data, the product $A r^{2}$ was plotted against $r$, where $A$ is the corrected foil activity and $r$ is the distance from the source to the detector. A smooth curve was drawn through the experimental points. This curve was used to construct the curve of $\mathrm{Ar}^{4}$ versus $\mathrm{r}$.

In order to evaluate the integrals of $\mathrm{Ar}^{2}$ and $\mathrm{Ar}^{4}$ from zero to infinity, the experimental curves of $\mathrm{Ar}^{2}$ were extrapolated to infinity by assuming(s) that the slowing-down density was proportional

to $\frac{e^{-r / \lambda}}{r^{2}}$ at distances greater than $30^{\circ} \mathrm{cm}$ from the source. The

parameter $\lambda$ was determined from the slope of the curve of In $\mathrm{Ar}^{2}$ versus $r$, at distances greater than $30 \mathrm{~cm}$ from the source. The portion of the area under the curve of $\mathrm{Ar}^{4}$ versus $\mathrm{r}$ beyond the last experimental point varied from eight to fifteen per cent of the total area, whereas the area under the extrapolated portion of the curve of $\mathrm{Ar}^{2}$ versus $r$ was less than one per cent of the total area.

After the curves were extrapolated, the integrals in Equation 2 were evaluated by measuring the area under the curves with a planimeter.

Figures 6, 7 , and 8 show the development of a typical set of curves, in the case of 94.0 per cent $D_{2} O$. Similar sets of curves were drawn for each of the other measurements. Figure 6 is a plot of in $\mathrm{Ar}^{2}$ versus $r$ from which the parameter $\lambda$ was determined, and Figures 7 and 8 are plots of $\mathrm{Ar}^{2}$ and $\mathrm{Ar}^{4}$ versus $r$. The ratio of the areas under the curves of $\mathrm{Ar}^{4}$ and $\mathrm{Ar}^{2}$ from $\mathrm{r}=0$ to $\mathrm{r}=\infty$ was $518 \mathrm{~cm}^{2}$. This result is the experimental value of $\overline{r^{2}}$. The neutron age is, by definition, one-sixth of $\overline{\mathrm{r}^{2}}$ and therefore equals $86 \mathrm{~cm}^{2}$, for 94.0 per cent $\mathrm{D}_{2} \mathrm{O}$.

\section{RESULTS}

Tables I through VII give the results of the foil measurements for the different slowing-down media. These results are also shown graphically in Figures 9 and 10, which are plots of in $\mathrm{Ar}^{2}$ versus $r$. The curves in Figure 9 were normalized so that the foil activity at $r=0$ was approximately the same for each mixture.

The values of $\tau$ calculated from these data are given in Table VIII. The errors in $\tau$ listed in the table were estimated from the uncertainty with which the curves of $\mathrm{Ar}^{4}$ and $\mathrm{Ar}^{2}$ versus $r$ were extrapolated beyond the last experimental point. The parameter $\lambda$, determined from curves of in Ar2 versus $r$, is listed in Column 4 of Table VIII. The fraction of the area under the Ar4 curves that were evaluated by extrapolation is listed in Column 5 .

A previous measurement (2) of the neutron age in $\mathrm{D}_{2} \mathrm{O}$ gave a result of $106 \mathrm{~cm}^{2}$ for 99.8 per cent $\mathrm{D}_{2} \mathrm{O}$. This result agrees with the present result within the experimental error. The variation in age as a function of light water contamination is shown in Figure 11 . Over 
this small range of moderator purities, the decrease in $\tau$ as a function of purity is very nearly linear. The slope of this line shows that one per cent of $\mathrm{H}_{2} \mathrm{O}$ decreases. $\tau$ by $4 \mathrm{~cm}^{2}$.

Experiments in the lattice of aluminum and heavy water showed that the age measured parallel to the aluminum rods was $140 \mathrm{~cm}^{2}$ and that the age measured perpendicular to the rods was $108 \mathrm{~cm}^{2}$. Figure 10 compares the curves of $1 n$ Ar ${ }^{2}$ versus $r$ that were obtained in the vertical and radial directions. The difference in the foil activities caused by the anisotropy in the age is noticeable at distances greater than $20 \mathrm{~cm}$ from the source and becomes more apparent as the distance increases. This anisotropy results from the streaming of fast neutrons along the aluminum rods. The value of $108 \mathrm{~cm}^{2}$ for the age measured in the direction perpendicular to the aluminum rods equals the value of the age for pure moderator within the precision of the measurements.

Since the radius of the tank was $76 \mathrm{~cm}$ while its height was $185 \mathrm{~cm}$, it was necessary to make sure that the differences in the slowing-down distributions in the radial and vertical directions were not influenced by leakage of neutrons in the radial direction. An auxiliary experiment in 99.0 per cent $\mathrm{D}_{2} \mathrm{O}$ showed that, with all aluminum removed, the slowing-down distributions were the same in both the radial and vertical directions. Therefore, the radial boundary, $76 \mathrm{~cm}$ from the source, did not affect the radial measurements in the mixture of $\mathrm{D}_{2} \mathrm{O}$ and aluminum.

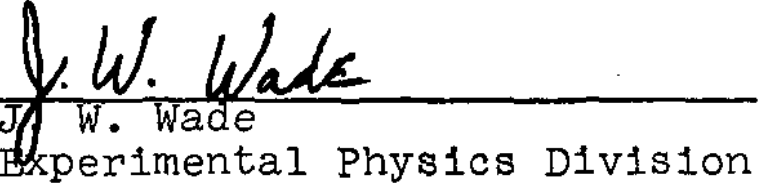




\section{APPENDIX}

CORRECTION OF FOIL ACTIVITIES FOR FINITE SIZE OF SOURCE AND DETECTORS

To account for the finite size of the foils and the source, geometric corrections must be applied to the activity of the indium foils. Such corrections have been published previously (s) for various shapes of folls and sources. For a plane source of radius $a_{1}$ and $a$ plane detector of radius $a_{2}$, the correction for the activity of the foil is

$$
A\left(r_{0}\right)-A_{m}\left(r_{0}\right)=-\left(\frac{a_{1}^{2}+a_{2}^{2}}{4 r_{0}}\right)\left(\frac{d A}{d r}\right) r_{0}
$$

where

$$
\begin{aligned}
A\left(r_{0}\right)= & \text { activity induced by a point source in a point detector } \\
& \text { at } r_{0} \\
A_{m}\left(r_{0}\right)= & \text { measured activity in the finite foil at } r_{0} \\
r_{0}= & \begin{array}{l}
\text { distance between the center of the fission source and the } \\
\text { foil }
\end{array}
\end{aligned}
$$

Since this correction was small, the derivative $\left(\frac{d A}{d r}\right)_{r_{0}}$, was taken to be the slope of the experimental curve of $A_{m}$ versus $r$.

The correction factor for a source with a radius of 1.0 inch and foils with radii of 0.750 inch is shown in Figure 12. In the range of the measurements that were used to calculate $\tau$, the correction was less than 0.5 per cent.

CORRECTIONS FOR ACTIVITY INDUCED IN THE FOIIS BY HIGH ENERGY NEUTRONS

The correction for the activation of the cadmium-covered indium folls by high energy neutrons was determined by experiment, by means of a technique that has been described previously (10). The technique consists of comparing the activity of indium folls covered by cadmium with the activity of folls covered by both cadmium and indium. Since the resonances of In-115 above $1.4 \mathrm{ev}$ are weak compared to the resonance at $1.4 \mathrm{ev}$, the self-shielding of the high energy resonances is small compared to that of the $1.4-e v$ resonance. Consequently, covering the folls with indium will have little effect on the activation by neutrons of higher energy, but will decrease the activation at $1.4 \mathrm{ev}$ by a large factor.

At distances less than $\sqrt{\tau}$ from the fission source, the total activation of cadmium-covered indium folls is 


$$
A_{\text {total }}=A(1.4 \mathrm{ev})+A(\text { high energy })
$$

At distances of two or three times $\sqrt{\tau}$ from the source, the activation by high energy neutrons is negligible so that the activation is

$$
A_{\text {total }}=A(1.4 \mathrm{ev})
$$

With the foils covered with both indium and cadmium, Equations 1 and 2 can be written

$$
\begin{aligned}
& A_{\text {total }}^{\prime}=\mathrm{g}_{\mathrm{O}} \mathrm{A}(1.4 \mathrm{ev})+\mathrm{A} \text { (high energy) } \\
& \mathrm{A}_{\text {total }}^{\prime}=\mathrm{g}_{\mathrm{O}} \mathrm{A}(1.4 \mathrm{ev})
\end{aligned}
$$

where $g_{\circ}$ is the self-shielding factor for the foll at the $1.4-\mathrm{ev}$ indium resonance. It is independent of $r$. Equations 2 and $2 a$ may be used to obtain go and then Equations 1 and la may be solved simultaneously to obtain A(high energy).

The table below lists the results of experiments with cadmium plus indium covers and with cadmium covers alone.

\begin{tabular}{rrrl}
$\begin{array}{r}r, \\
\mathrm{~cm}\end{array}$ & $\mathrm{~A}_{\mathrm{Cd}}$ & $\mathrm{A}_{\mathrm{Cd}}+\mathrm{In}_{2}$ & $\frac{\mathrm{A}_{\mathrm{Cd}}+\mathrm{In}}{\mathrm{A}_{\mathrm{Cd}}}$ \\
\hline 4.4 & 513,300 & 228,470 & 0.445 \\
14.0 & 305,020 & 128,180 & 0.420 \\
31.5 & 57,200 & 22,390 & 0.392 \\
42.0 & 13,650 & 5,194 & 0.381 \\
\hline
\end{tabular}

Figure 13 is a plot of the ratio of the indium foll activities when covered with indium plus cadmium to the activities when covered with cadmium. At distances greater than $25 \mathrm{~cm}$ from the fission source this ratio equals go. From Figure 13, go equals 0.38 . The resulting correction to the foil activity is plotted also in Figure 13 and 1 s less than 0.5 per cent for distances greater than $25 \mathrm{~cm}$ from the source. 


\section{BIBLIOGRAPHY}

1. Glasstone, S. and Edlund, M. C. The Elements of Nuclear Reactor Theory. New York: Van Nostrand Co., Inc. (1952).

2. Friedman, F. L. and Wattenberg, A. Age of Fission Neutrons in $\mathrm{D}_{2} \mathrm{O}$. Chicago Univ. Metallurgical Lab. CP-3453, March 1946 (Declassified).

3. Rose, M. E. The Slowing Down Length in Mixtures. Clinton Laboratories MonP-255 (Declassified).

4. Kaplan, I. and Chernick, J. The Brookhaven Nuclear Reactor: Theory and Nuclear Design Calculations. Brookhaven National Lab. BNL-152, January 1952 (Declassified).

5. Bothe, W. "Theory of the Method of Neutron Probes." Zeits. f. Physik 120, 437-49 (1943).

6. Axtmann, R. C. and Towler, O. A. E. I. du Pont de Nemours \& Co. DP-49, October 1954 (Classified).

7. Axtmann, R. C. et al. E. I. du Pont de Nemours \& Co. DP-32, December 1953 (Classified).

8. Stewart, H. B. et al. "Low-Power Thermal Test Reactor for Nuclear Physics Research." Nucleonics 1, No. 5, 38-41 (May 1953).

9. Hill, J. E., Roberts, L. D., and Fitch, r. E. The Slowing Down Distribution from a Point Source of Fission Neutrons in Light Water. Oak Ridge National Lab. AECD-3392, Dec. 1948 (Declassified).

10. Roberts, L. D. et al. "Study of the Slowing Down Distribution of $\mathrm{Sb}^{124}$-Be Photo-Neutrons in Graphite, and of the Use of Indium Foils." Phys. Rev. 80, 6 (1950). 
TABLE I

MEASUREMENTS IN $\mathrm{AL}-\mathrm{D}_{2} \mathrm{O}$ LATTICE

\begin{tabular}{|c|c|c|c|c|}
\hline \multicolumn{5}{|c|}{$\begin{array}{l}\mathrm{D}_{2} \mathrm{O} \text { Purity }=99.3 \% \\
\text { Placement of Fo11 }\end{array}$} \\
\hline $\begin{array}{l}\text { Angle from } \\
\text { Vertical Iine } \\
\text { through Source, } \\
\quad \text { degrees } \\
\end{array}$ & $\begin{array}{l}\text { Foll } \\
\text { Placed } \\
\text { Inside } \\
\text { of }\end{array}$ & $\begin{array}{c}\text { Distance } \\
\text { from Source } \\
\mathrm{r}, \\
\mathrm{cm}\end{array}$ & $\begin{array}{l}\text { Acorrected, } \\
\text { Relative cts } / \mathrm{min}\end{array}$ & $A \mathrm{C}^{2} \times 10^{-6}$ \\
\hline 0 & Al & 2.4 & 267,461 & 1.50 \\
\hline 0 & AI & 4.4 & 251,440 & 4.96 \\
\hline 0 & Al & 9.4 & 219,807 & 19.58 \\
\hline 0 & $\mathrm{Al}$ & 11.9 & 182,919 & 26.07 \\
\hline 0 & Al & 14.0 & 160,250 & 31.31 \\
\hline 10 & $\mathrm{D}_{2} \mathrm{O}$ & 15.8 & 144,217 & 36.11 \\
\hline 0 & AI & 21.4 & 84,909 & 39.02 \\
\hline 0 & $\mathrm{Al}$ & 21.5 & 84,759 & 39.23 \\
\hline 0 & Al & 24.4 & 62,405 & 37.27 \\
\hline 0 & Al & 26.0 & 56,222 & 37.93 \\
\hline 8 & $\mathrm{D}_{2} \mathrm{O}$ & 31.1 & 27,531 & 26.70 \\
\hline 0 & Al & 31.5 & 28,313 & 28.12 \\
\hline 0 & $\mathrm{Al}$ & 34.0 & 20,811 & 24.02 \\
\hline 0 & Al & 34.1 & 20,341 & 23.59 \\
\hline 0 & Al & 37.0 & 13,042 & 17.84 \\
\hline 0 & Al & 37.0 & 13,442 & 18.39 \\
\hline 0 & $\mathrm{Al}$ & 42.1 & 6,809 & 12.04 \\
\hline 5 & $\mathrm{D}_{2} \mathrm{O}$ & 43.1 & 5,474 & 10.15 \\
\hline 5 & $\mathrm{D}_{2} \mathrm{O}$ & 47.0 & 2,634 & 5.82 \\
\hline 3 & $\mathrm{D}_{2} \mathrm{O}$ & 50.7 & 1,644 & 4.22 \\
\hline 0 & Al & 59.5 & 600 & 2.13 \\
\hline 2 & $\mathrm{D}_{2} \mathrm{O}$ & 63.8 & 243 & 0.99 \\
\hline 0 & Al & 64.5 & 294 & 1.22 \\
\hline 0 & $\mathrm{Al}$ & 72.1 & 804 & 0.42 \\
\hline 0 & Al & 76.1 & 80 & 0.46 \\
\hline \multirow[t]{2}{*}{45} & $\mathrm{D}_{2} \mathrm{O}$ & 19.9 & 96,694 & 38.15 \\
\hline & & 31.1 & 24,940 & 24.17 \\
\hline 90 & $\mathrm{D}_{2} \mathrm{O}$ & 6.1 & 273,632 & 10.15 \\
\hline 90 & $\mathrm{D}_{2} \mathrm{O}$ & 7.9 & 253,109 & 15.86 \\
\hline 270 & $\mathrm{D}_{2} \mathrm{O}$ & 14.0 & 169,153 & 34.05 \\
\hline 90 & $\mathrm{D}_{2} \mathrm{O}$ & $17 \cdot 7$ & 117,324 & 36.67 \\
\hline 90 & $\mathrm{D}_{2} \mathrm{O}$ & 23.9 & 62,883 & 35.80 \\
\hline 270 & $\mathrm{D}_{2} \mathrm{O}$ & 31.8 & 21,766 & 22.03 \\
\hline 90 & $\mathrm{D}_{2} \mathrm{O}$ & 35.5 & 14,286 & 18.04 \\
\hline 270 & $\mathrm{D}_{2} \mathrm{O}$ & 35.5 & 35,567 & 19.66 \\
\hline 270 & $\mathrm{D}_{2} \mathrm{O}$ & 42.2 & 3,530 & 6.29 \\
\hline \multirow[t]{2}{*}{90} & $\mathrm{D}_{2} \mathrm{O}$ & 43.0 & 2,684 & 4.97 \\
\hline & & $-15-$ & & \\
\hline
\end{tabular}




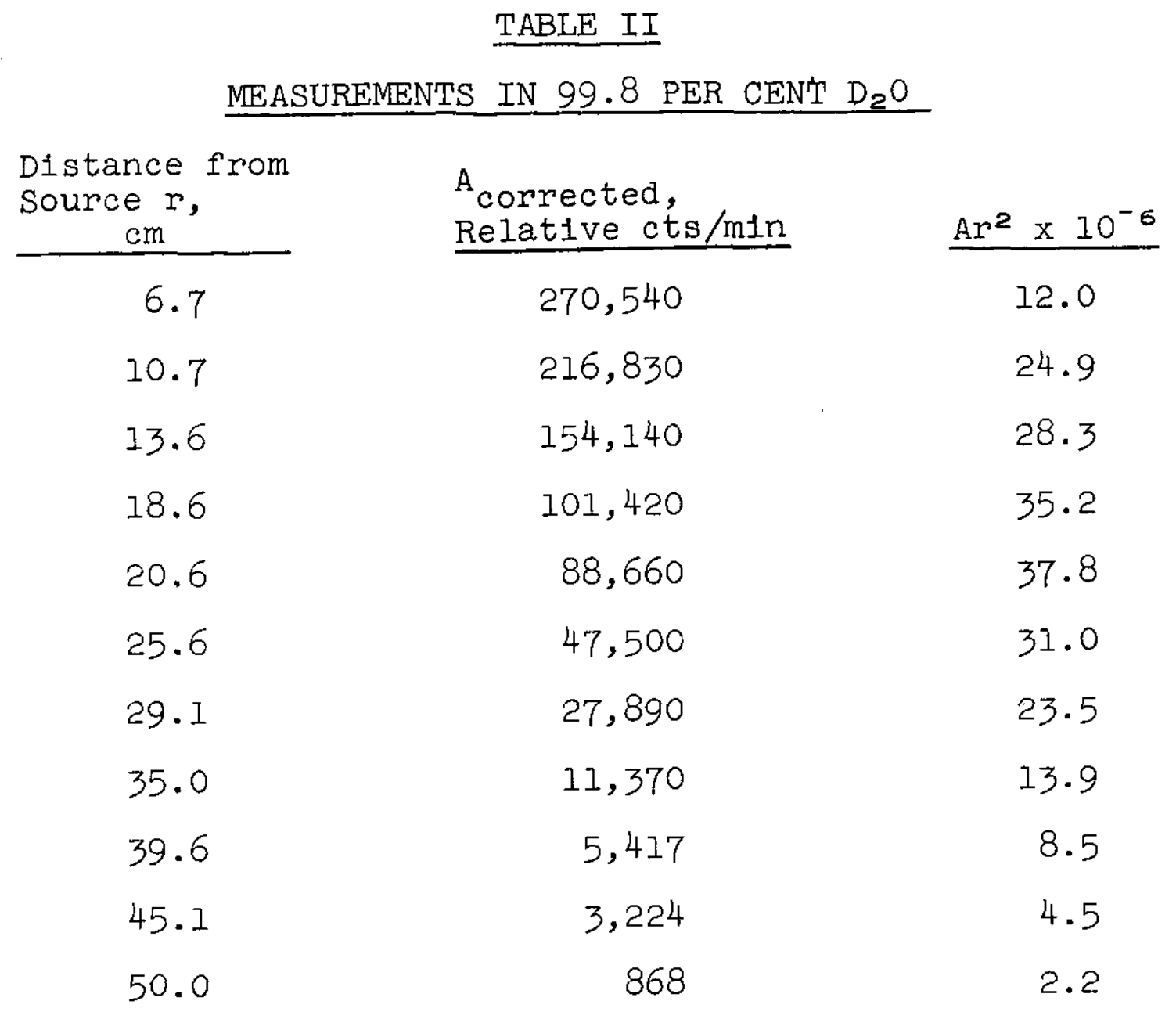


TABLE III

MEASUREMENTS IN 99.0 PER CENT $\mathrm{D}_{2} \mathrm{O}$

Distance From

Source $r$,

$\mathrm{cm}$

Acorrected,

Relative cts/min

$\mathrm{Ar}^{2} \times 10^{-6}$

6.2

382,900

14.66

10.2

301,200

31.07

13.4

217,600

39.23

19.6

125,400

48.18

20.5

110,100

46.26

24.9

59,600

37.01

$29 \cdot 7$

31,110

27.38

30.5

28,300

26.29

34.1

16,010

18.67

38.8

6,910

10.38

40.0

4,072

7.54

49.9

928

$2 \cdot 31$

50.0

1,056

2.64 


\begin{tabular}{c} 
MEASUR \\
$\begin{array}{c}\text { Distance from } \\
\text { Source } r\end{array}$ \\
\hline 6.5 \\
10.8 \\
14.5 \\
18.7 \\
20.6 \\
24.9 \\
29.1 \\
35.0 \\
39.7 \\
45.1 \\
50.1
\end{tabular}

TABLE IV

MEASUREMENTS IN 98.4 PER CENT $\mathrm{D}_{3} \mathrm{O}$

Distance from source $r$,

$$
6.5
$$

10.8

14.5

18.7

20.6

Acorrected, $/ \mathrm{min}$
Relative cts
329,030
238,190
165,630
106,810
82,320
45,940
24,960
11,050
5,270
2,447
1,372

Ar $^{2} \times 10^{-6}$
14.0
27.7
34.9
37.5
35.1
28.5
21.2
13.5
8.3
5.0
3.4




\section{TABLE V}

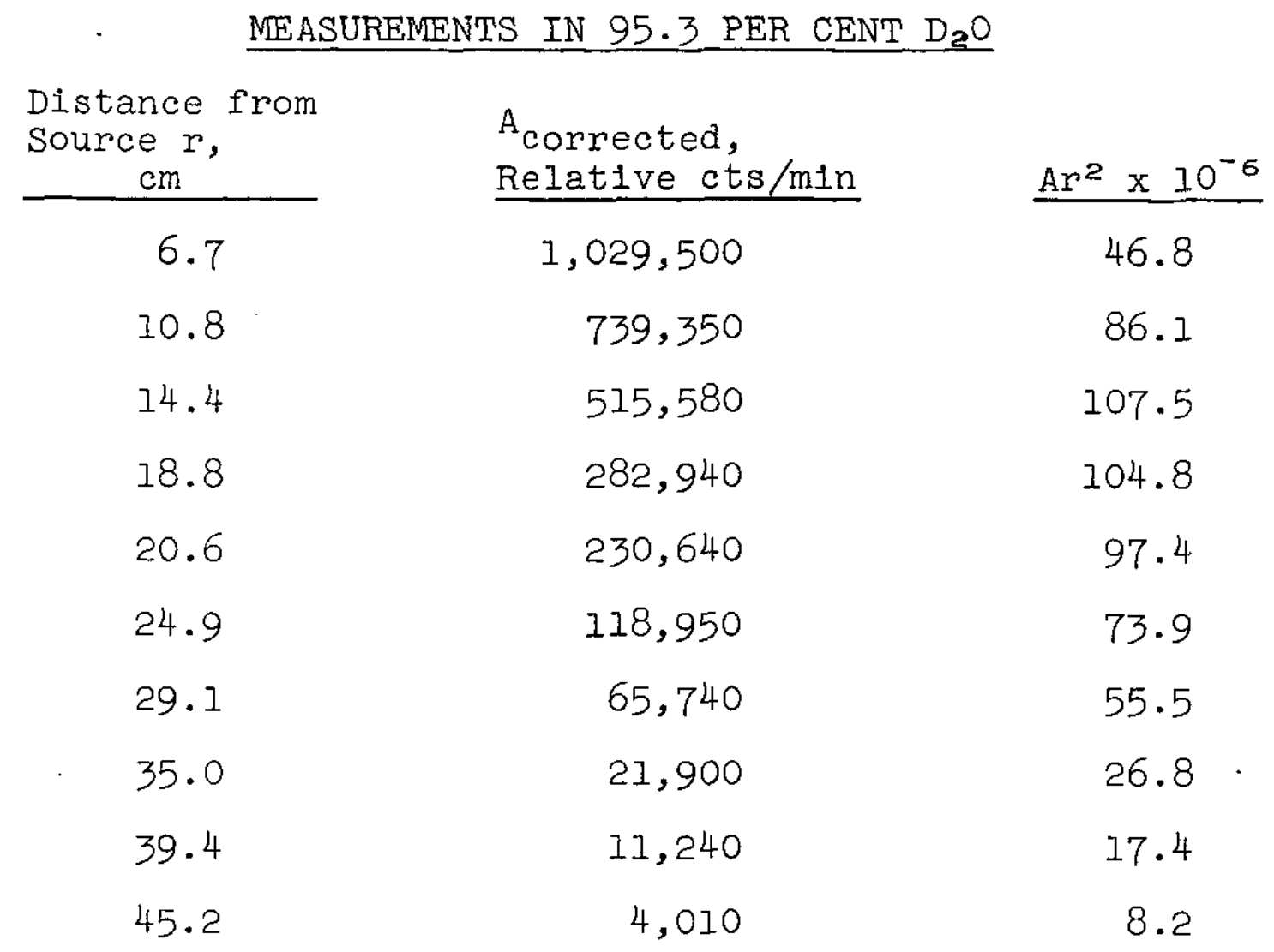




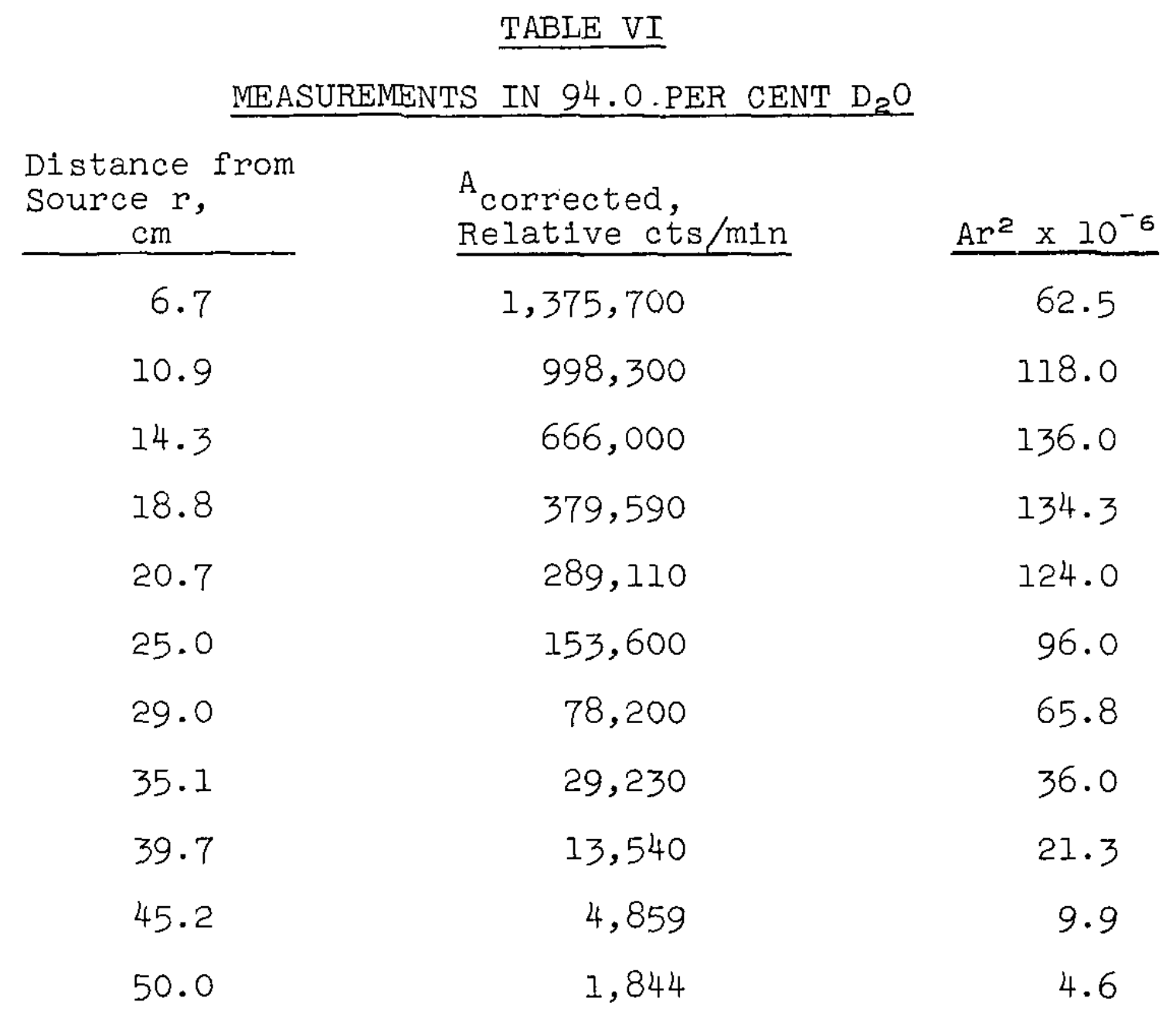


TABLE VII

MEASUREMENTS IN 91.8 PER CENT $\mathrm{D}_{2} \mathrm{O}$

Distance from

Source $r$,

$\mathrm{cm}$

6.7

10.8

14.4

18.8

20.6

25.0

29.1

35.0

39.6

45.2
A corrected,

Relative cts/min

$1,055,020$

732,240

473,570

261,760

201,640

98,800

49,110

17,700

7,616

2,030
$\mathrm{Ar}^{2} \times 10^{-6}$

47.9

85.3

98.7

92.6

85.8

61.8

41.7

21.7

12.0

4.1 


\section{TABLE VIII}

\section{SUMMARY OF AGE MEASUREMENTS}

$\begin{array}{llll}\begin{array}{l}\text { Slowing-Down Media, } \\ \text { Per Cent } \mathrm{D}_{2} \mathrm{O}\end{array} & \underline{\begin{array}{c}\tau, \\ \mathrm{cm}^{2}\end{array}} & \begin{array}{l}\text { Estimated } \\ \mathrm{cm}^{2}\end{array} & \begin{array}{l}\lambda, \\ \mathrm{cm}\end{array}\end{array}$

A. In Water

$\begin{array}{lrrrr}99.8 & 109 & \pm 3 & 8.7 & 13 \\ 99.0 & 107 & \pm 5 & 8.7 & 14 \\ 98.4 & 106 & \pm 3 & 9.3 & 15 \\ 95.3 & 93 & \pm 3 & 9.0 & 13 \\ 94.0 & 86 & \pm 3 & 7.5 & 8 \\ 91.8 & 78 & \pm 3 & 6.7 & 9\end{array}$

B. In $\mathrm{Al}-\mathrm{D}_{2} \mathrm{O}$ with 99.3 Per Cent $\mathrm{D}_{2} \mathrm{O}$

Parallel to aluminum

140

$\pm 3$

10.2

4

Perpendicular to aluminum rods 108

$\pm 5$

7.8

20 
FIGURE I

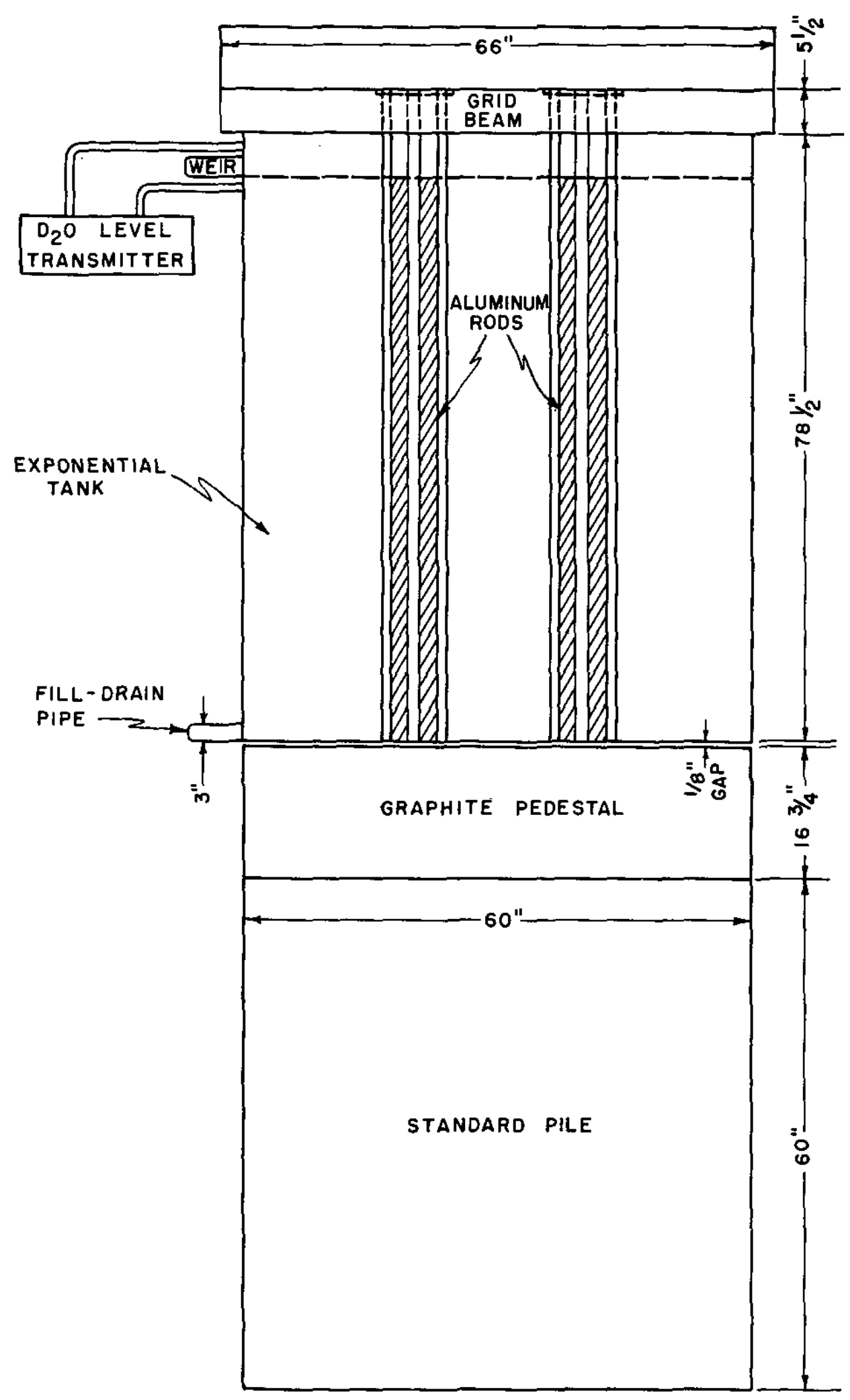

SIMPLIFIED ELEVATION OF THE EXPONENTIAL AND STANDARD PILE 


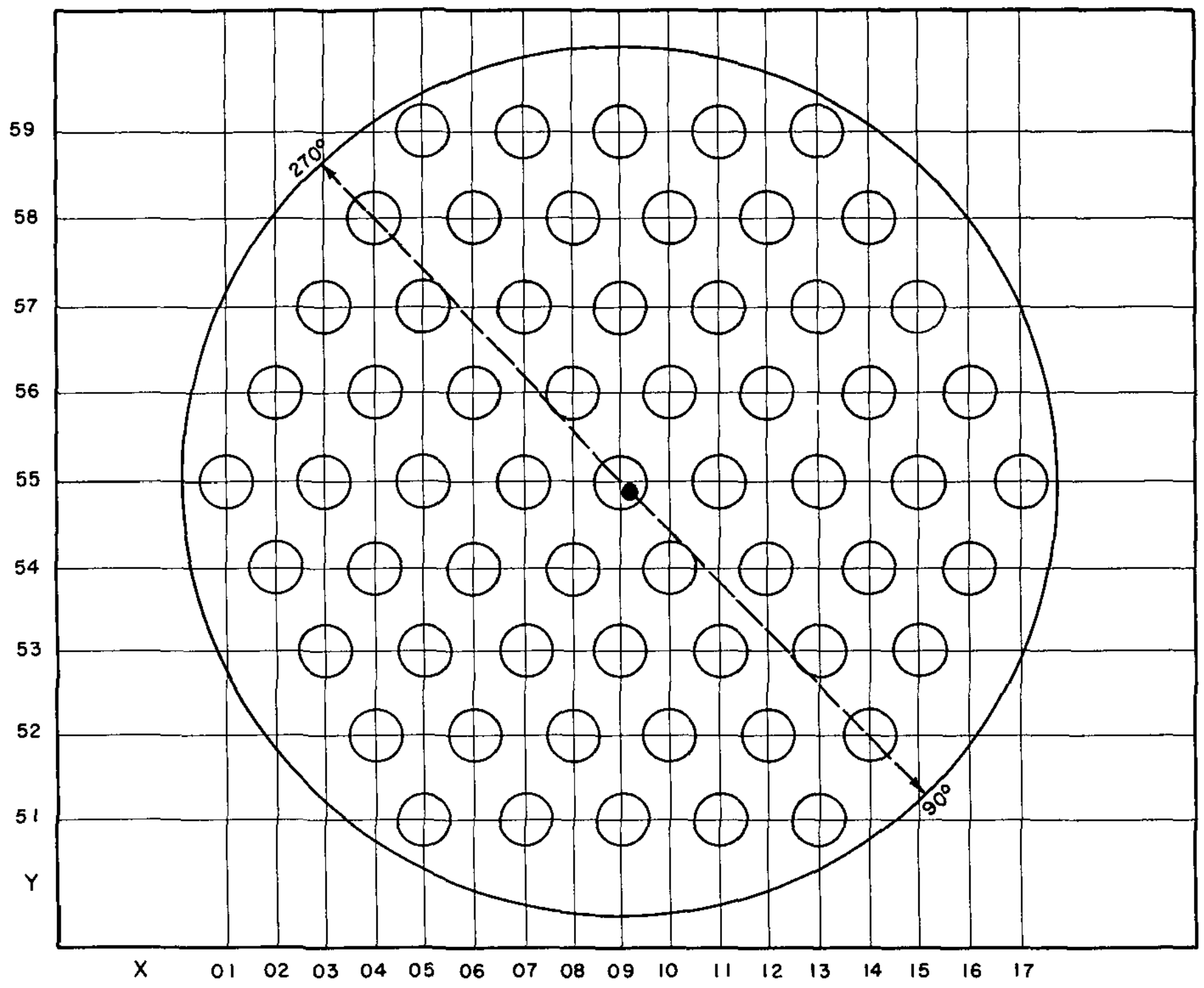

$\bigcirc$ Quatrefoils with Aluminum Rods

(9osition of Fission Source

- - Path of Rodial Traverses

DIAGRAM OF AI-D 2 O LATTICE 


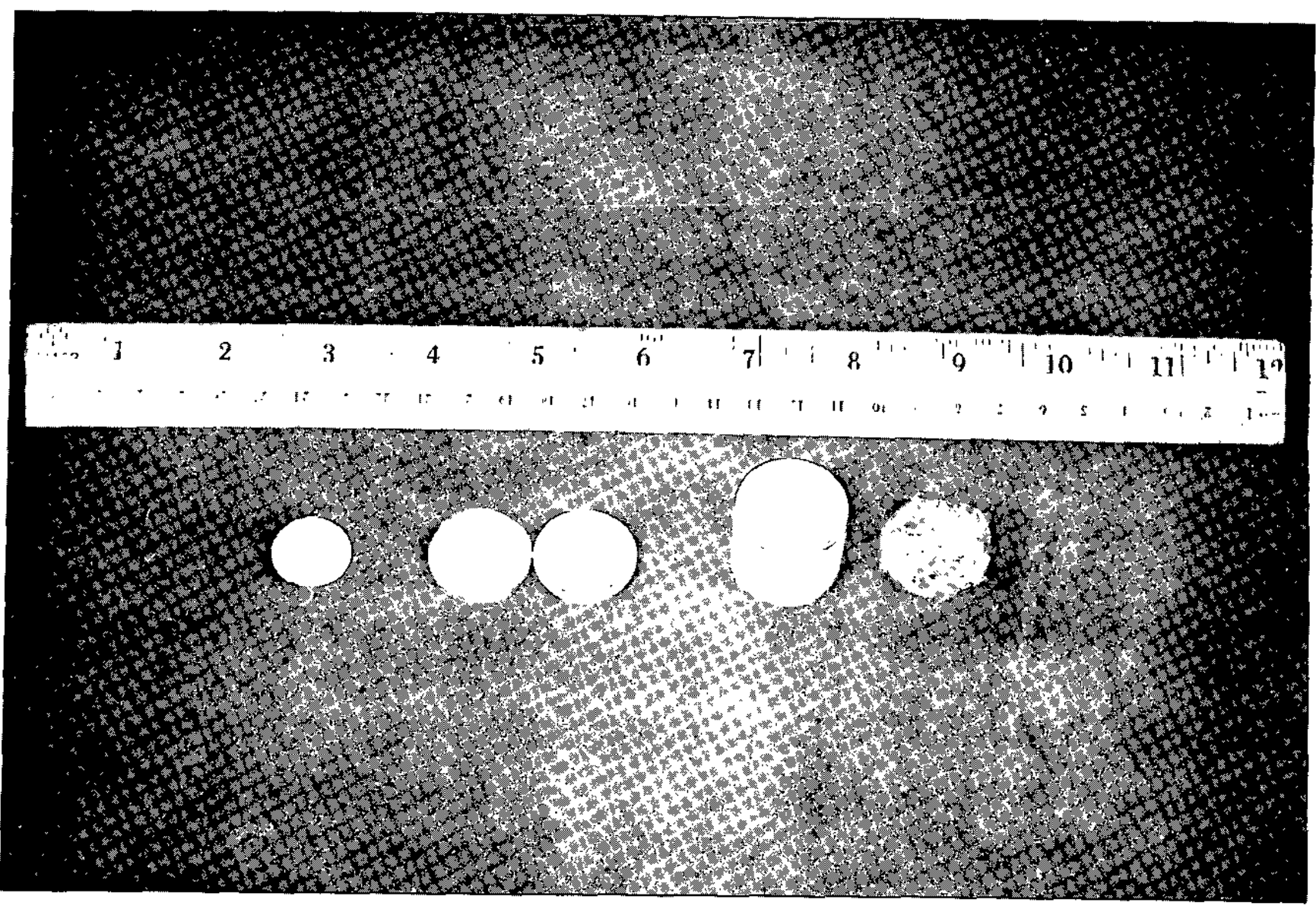

INDIUM FOIL, CADMIUM BOX, ALUMINUM FOIL HOLDER, AND FISSION SOURCE 


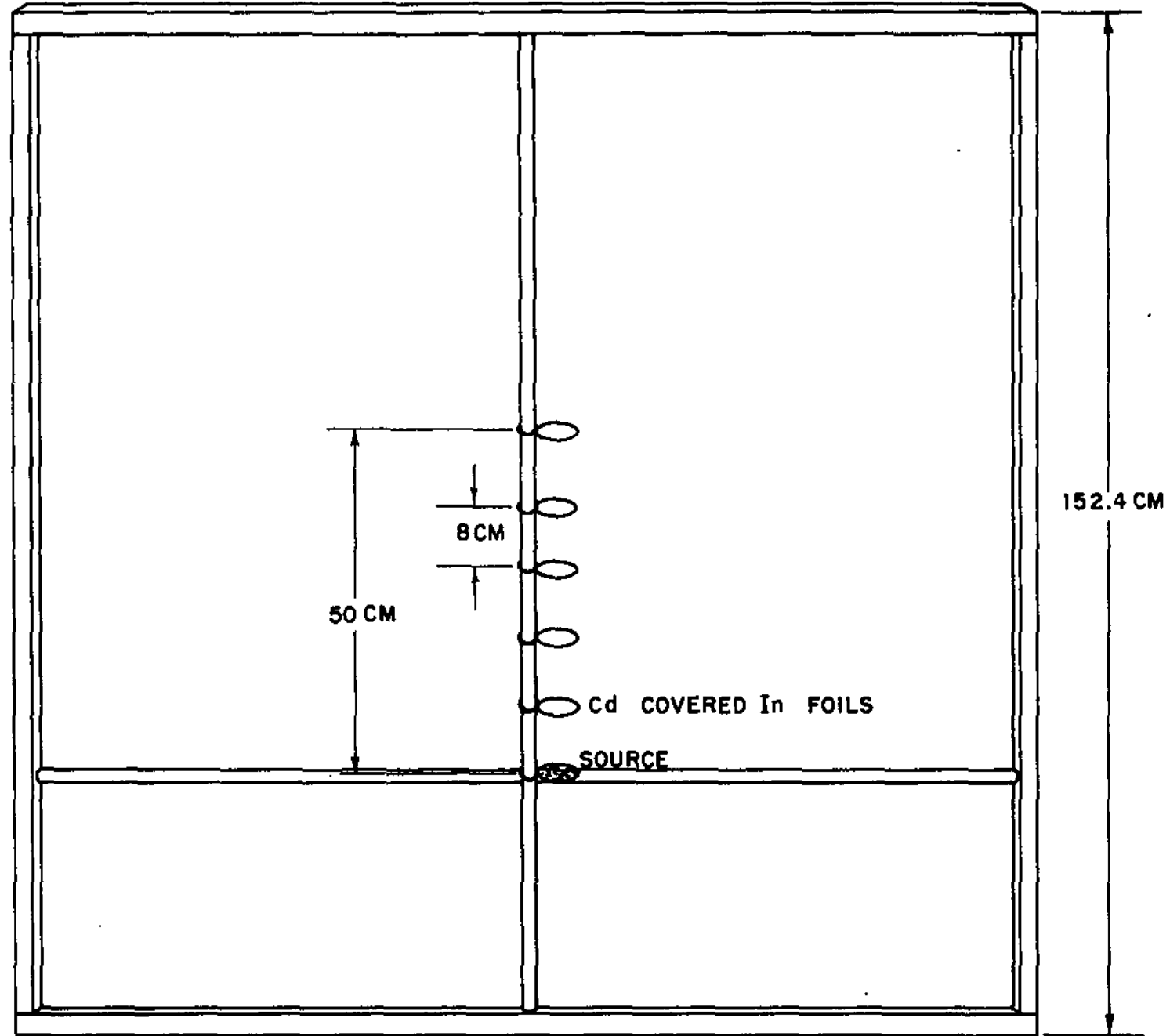

EXPERIMENTAL ASSEMBLY FOR MEASUREMENTS

IN THE $\mathrm{H}_{2} \stackrel{\mathrm{O}-\mathrm{D}_{2} \text { O MIXTURES }}{\mathrm{O}}$

$-26-$ 


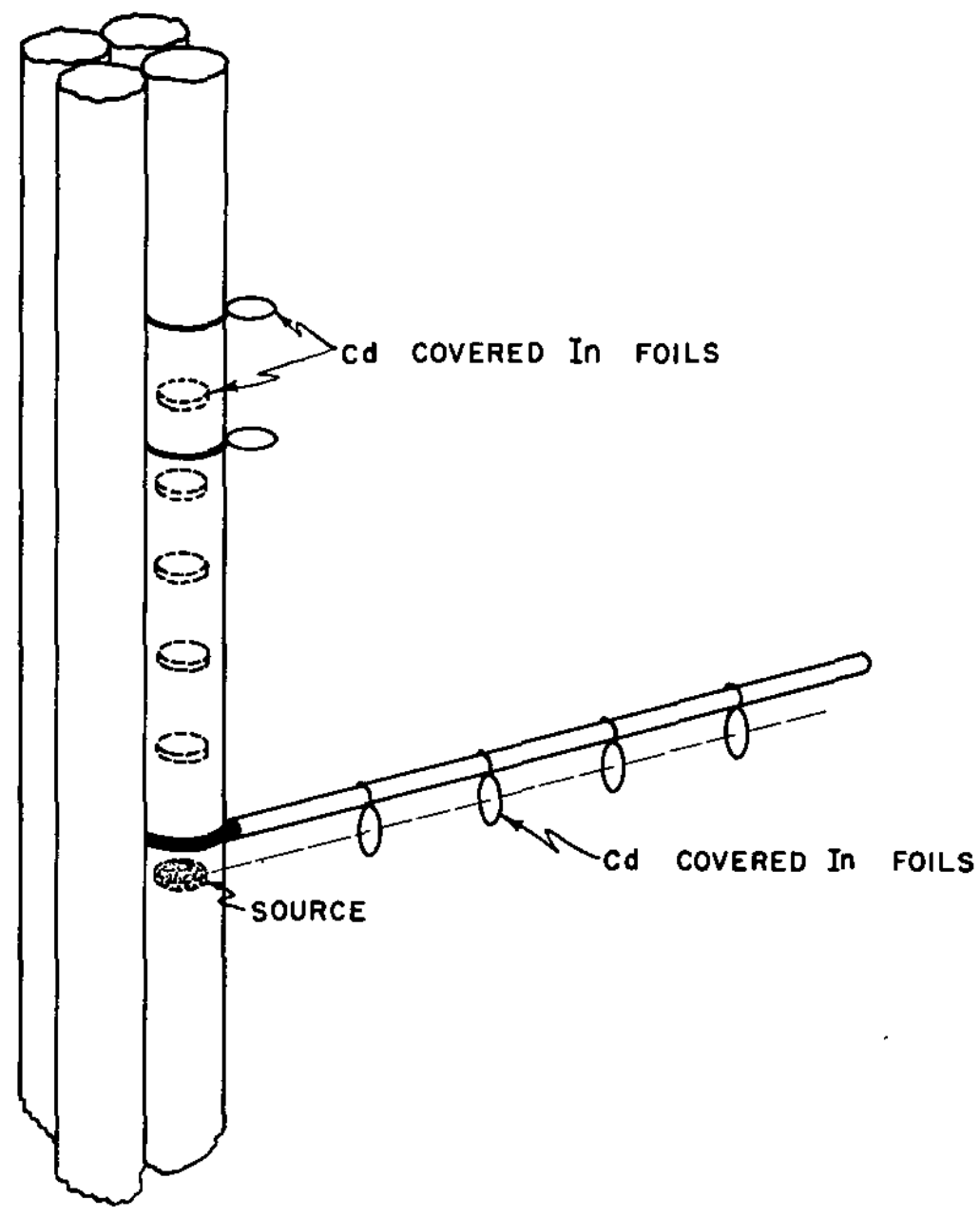

EXPERIMENTAL ASSEMBLY FOR RADIAL AND VERTICAL

TRAVERSES IN THE AI- $D_{2} 0$ LATTICE 


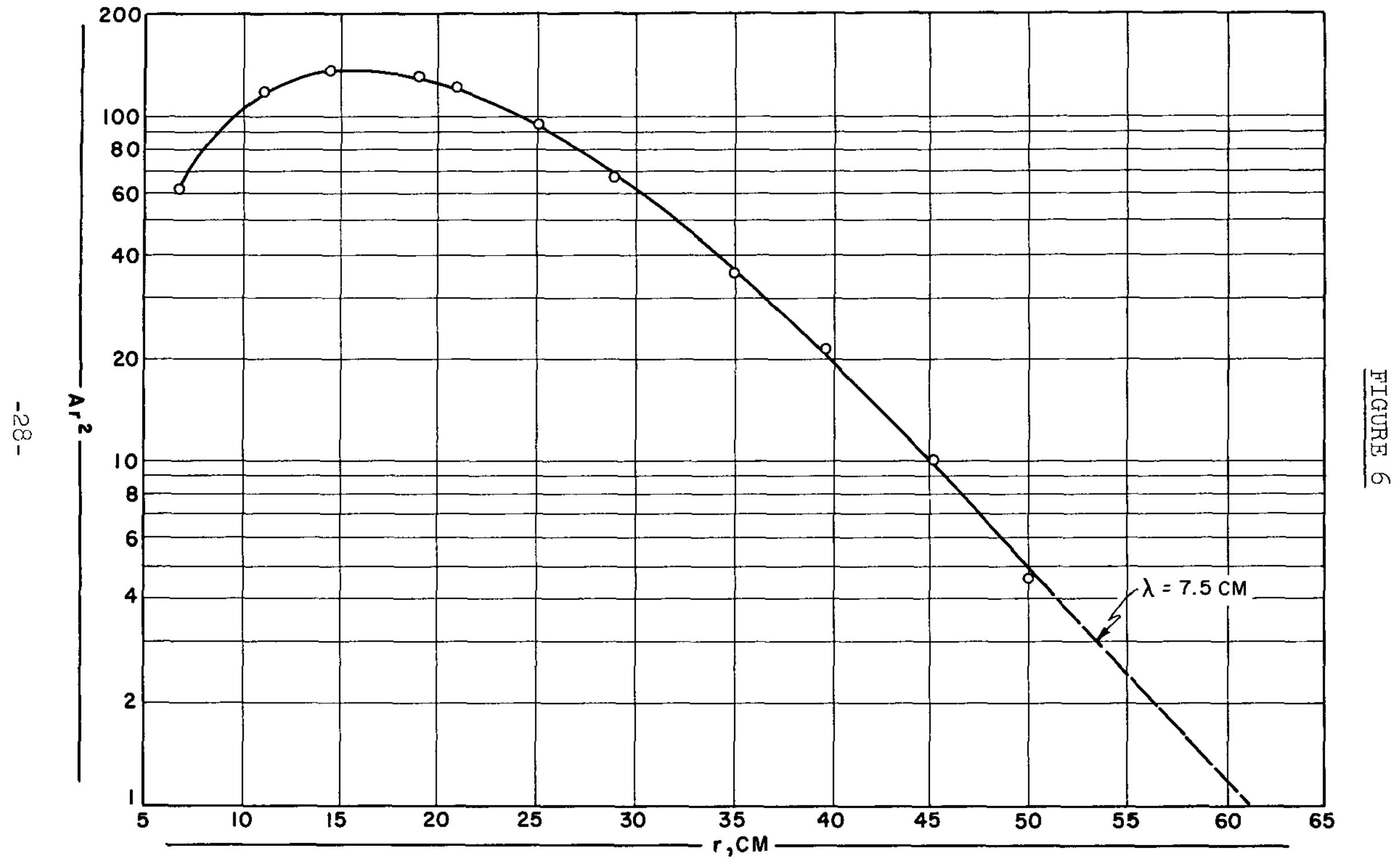

In $A r^{2}$ VS. I FOR 94.0 PER CENT $D_{2}$ 으 


$$
\frac{n}{-}
$$




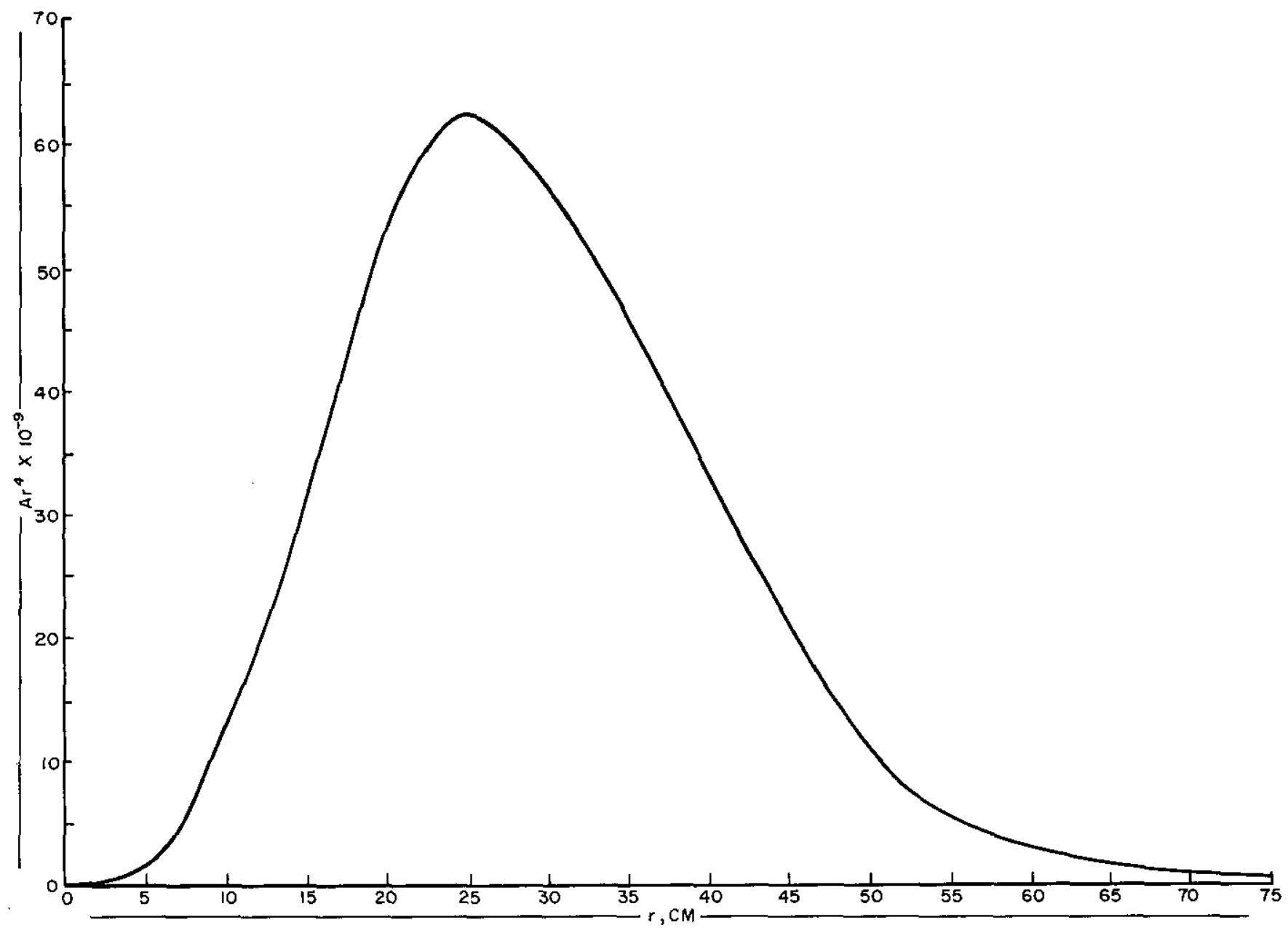

$\mathrm{Ar}^{4}$ VS. $\mathrm{r}$ FOR 94.0 PER CENT $\mathrm{D}_{2} \mathrm{O}$

$-30-$ 
FIGURE 9

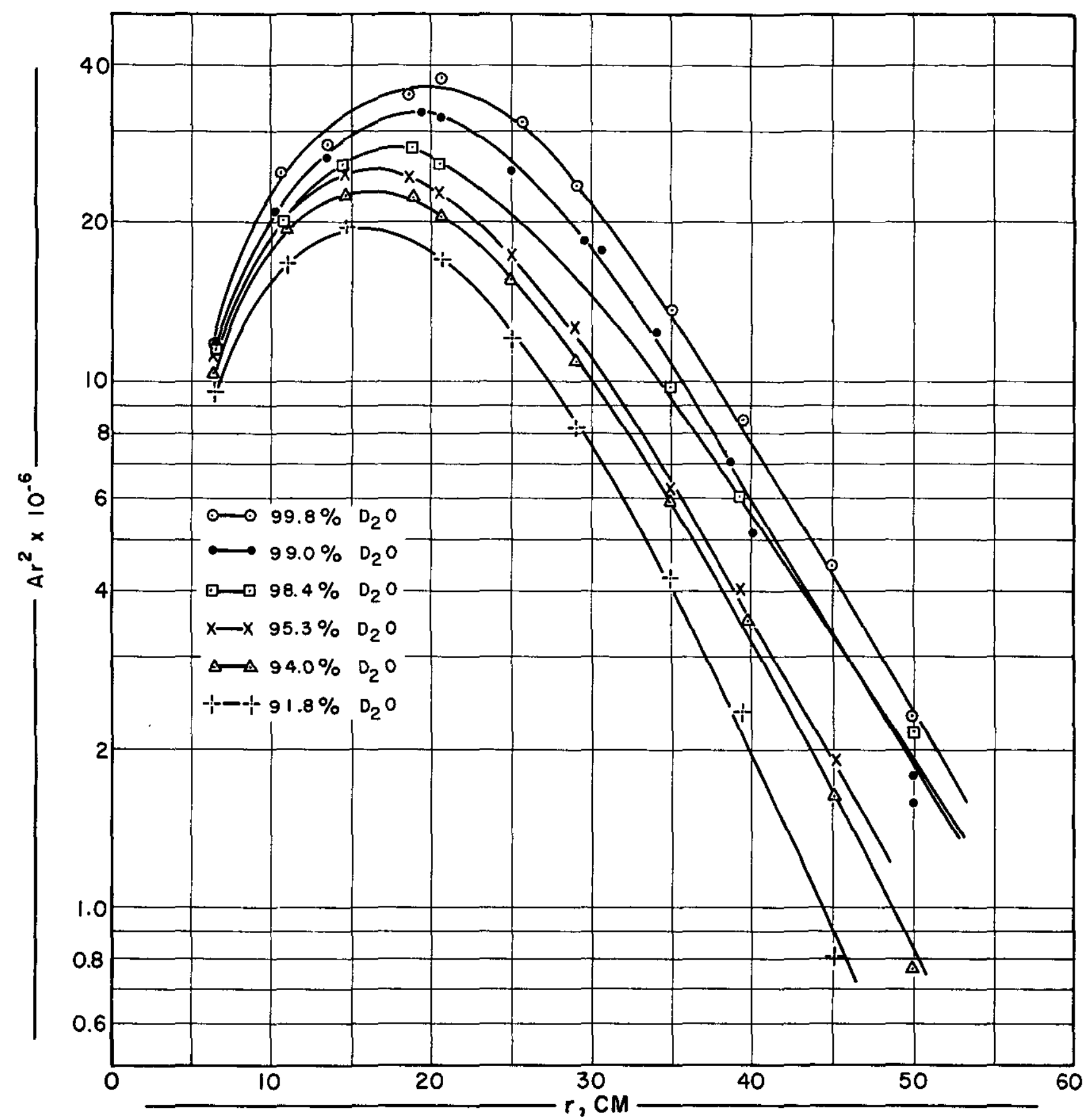

In $\mathrm{Ar}^{2}$ VS. $\mathrm{r}-\mathrm{H}_{2} \mathrm{O}-\mathrm{D}_{2} \mathrm{O}$ MIXTURES 


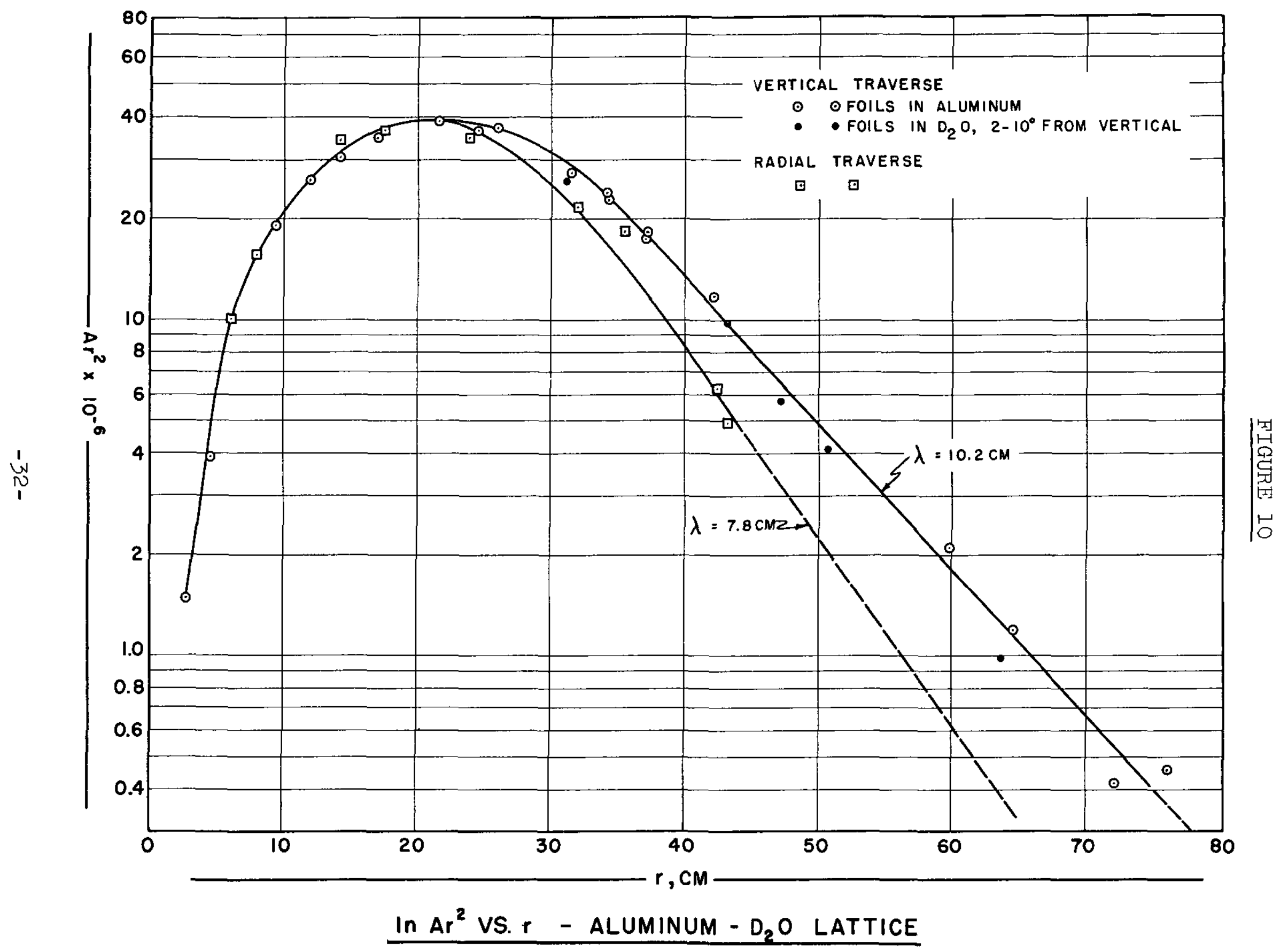


FIGURE 11

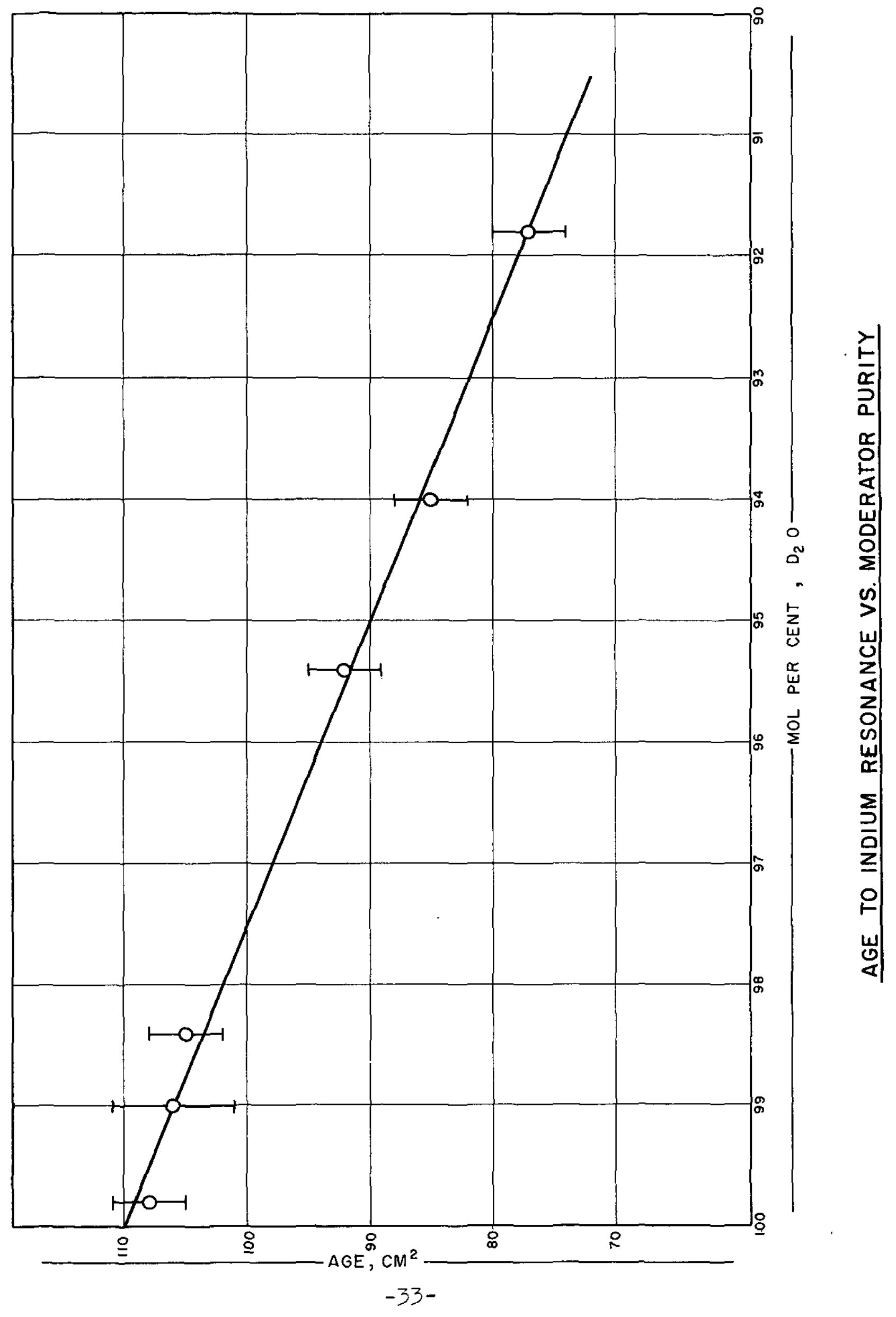




\section{FIGURE 12}

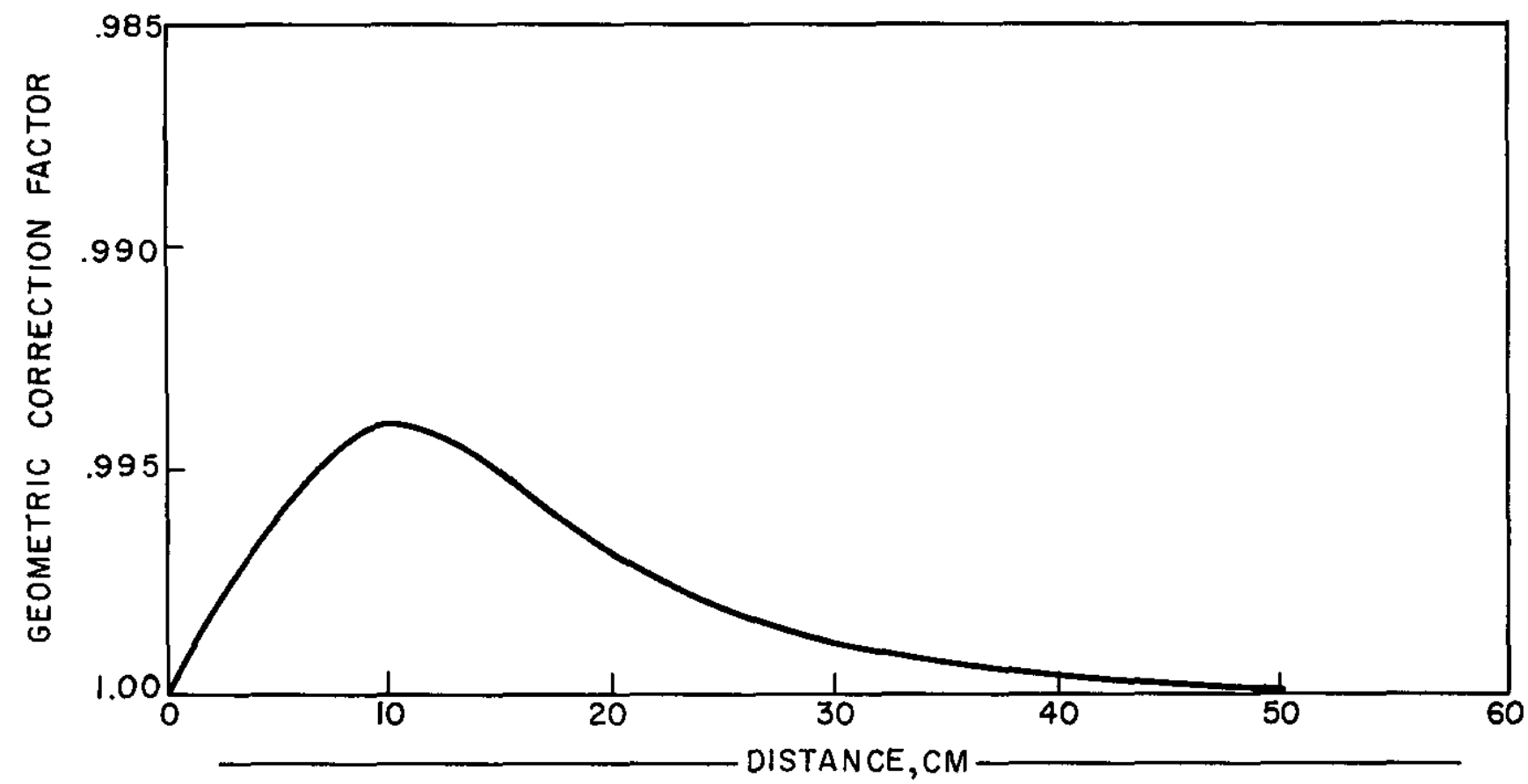

GEOMETRIC CORRECTION FACTOR VS. DISTANCE

$-34-$ 


\section{FIGURE 13}

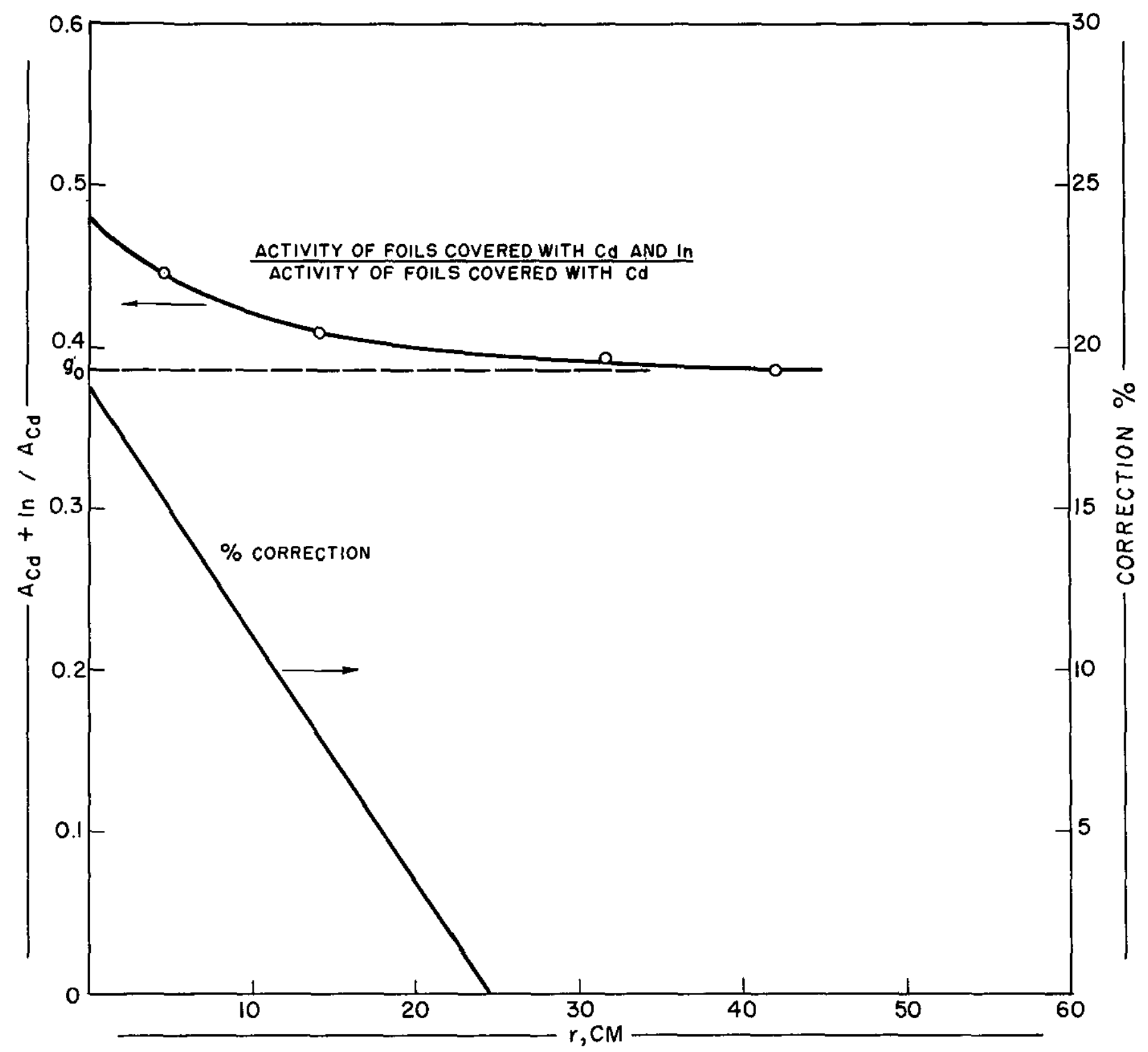

CORRECTION OF FOIL ACTIVITY FOR HIGH ENERGY NEUTRONS VS. $r$ 